\title{
Spatial Heterogeneity of Soil Nutrients after the Establishment of Caragana intermedia Plantation on Sand Dunes in Alpine Sandy Land of the Tibet Plateau
}

\author{
Qingxue $\mathrm{Li}^{1}$, Zhiqing $\mathrm{Jia}^{1}{ }^{*}$, Yajuan $\mathrm{Zhu}^{1}$, Yongsheng Wang ${ }^{1}$, Hong $\mathrm{Li}^{2}$, Defu Yang ${ }^{3}$, \\ Xuebin Zhao ${ }^{3}$
}

1 Institute of Desertification Studies, Chinese Academy of Forestry, Beijing, 100091, China, 2 Research Institute of Forestry, Chinese Academy of Forestry, Beijing 100091, China, 3 Sand Control Experimental Station of Qinghai Province, Gonghe 813005, Qinghai, China

* jiazq369@caf.ac.cn

\section{OPEN ACCESS}

Citation: Li Q, Jia Z, Zhu Y, Wang Y, Li H, Yang D, et al. (2015) Spatial Heterogeneity of Soil Nutrients after the Establishment of Caragana intermedia Plantation on Sand Dunes in Alpine Sandy Land of the Tibet Plateau. PLoS ONE 10(5): e0124456. doi:10.1371/ journal.pone. 0124456

Academic Editor: Sergio R. Roiloa, University of A Coruña, SPAIN

Received: May 8, 2014

Accepted: March 12, 2015

Published: May 6, 2015

Copyright: $\odot 2015 \mathrm{Li}$ et al. This is an open access article distributed under the terms of the Creative Commons Attribution License, which permits unrestricted use, distribution, and reproduction in any medium, provided the original author and source are credited.

Data Availability Statement: All relevant data are within the paper and its Supporting Information files.

Funding: This research was supported by the National Science \& Technology Pillar Program during the Twelfth Five-year Plan Period: Excellent sandfixation plant materials selecting and matching techniques researching (2012BAD16B0102); and the Forestry Public Benefit Scientific Research Special Project of P.R.China (201204203). The funders had no role in study design, data collection and analysis, decision to publish, or preparation of the manuscript.

\section{Abstract}

The Gonghe Basin region of the Tibet Plateau is severely affected by desertification. Compared with other desertified land, the main features of this region is windy, cold and short growing season, resulting in relatively difficult for vegetation restoration. In this harsh environment, identification the spatial distribution of soil nutrients and analysis its impact factors after vegetation establishment will be helpful for understanding the ecological relationship between soil and environment. Therefore, in this study, the 12-yearold $C$. intermediaplantation on sand dunes was selected as the experimental site. Soil samples were collected under and between shrubs on the windward slopes, dune tops and leeward slopes with different soil depth. Then analyzed soil organic matter (SOM), total nitrogen (TN), total phosphorus (TP), total potassium (TK), available nitrogen (AN), available phosphorus (AP) and available potassium (AK). The results showed that the spatial heterogeneity of soil nutrients was existed in C. intermedia plantation on sand dunes. (1) Depth was the most important impact factor, soil nutrients were decreased with greater soil depth. One of the possible reasons is that windblown fine materials and litters were accumulated on surface soil, when they were decomposed, more nutrients were aggregated on surface soil. (2) Topography also affected the distribution of soil nutrients, more soil nutrients distributed on windward slopes. The herbaceous coverage were higher and C. intermedia ground diameter were larger on windward slopes, both of them probably related to the high soil nutrients level for windward slopes. (3) Soil "fertile islands" were formed, and the "fertile islands" were more marked on lower soil nutrients level topography positions, while it decreased towards higher soil nutrients level topography positions. The enrichment ratio $(E)$ for TN and AN were higher than other nutrients, most likely because $C$. intermediais a leguminous shrub. 
Competing Interests: The authors have declared that no competing interests exist.

\section{Introduction}

Desertification is one of the main types of land degradation in arid, semi-arid and dry subhumid areas and results from various factors, including climatic variability and human activities [1]. Land desertification affects $25 \%$ of the total land area on Earth, impacting over 250 million people [2]. Sand mobility and wind erosion result in coarse, poor soil and low land productivity, which can degrade the human living environment and impede socioeconomic development. As China has been severely affected by desertification, desertification control is considered a principal strategy for maintaining ecological security in northern China. Vegetation restoration is a common and effective way to combat and control desertification [3], and it has undoubtedly contributed to an improvement in environmental conditions, as well as the promotion of sustainable development of China's dry lands [4].

The Gonghe Basin of the Tibet Plateau is severely affected by desertification, with a desertification area of $1.27 \times 10^{4} \mathrm{~km}^{2}$, which accounts for $91.9 \%$ area of the basin [5]. Caragana intermedia Kuang et H. C. Fu [6, 7], a perennial leguminous shrub, has been widely planted after the erection of straw checkerboards on shifting sand dunes in this region. Legume shrub species may be a critical regulator of soil nutrient dynamics because of their high foliar nitrogen and potential for symbiotic nitrogen fixation [8]. Previous studies have shown that the existed of leguminous shrub resulted in spatial heterogeneity of soil properties. For instance, some studies have shown that after the establishment of Caragana microphylla plantation on sand dunes, soil nutrient concentrations were higher under the shrubs than outside the canopies [9-10]. Retama sphaerocarpa is a leguminous shrub found in most regions of Spain, frequently with a growth of herbs in its understorey which increased the production of litter, and the interception of wind-blown dust, forming so-called "islands of fertility" [11-13]. The studies of Caragana tibetica nebkhas on the Inner Mongolia Plateau have shown that the "fertile islands" are formed inside and underneath C. tibetica nebkhas [14]. Formation of "fertile islands" increases spatial heterogeneity in soil resources [15], and affects not only seedling establishment [16], but also the spatial distribution of plant productivity and diversity [17-18].

All of the above studies analyzed the spatial distribution of soil nutrients in other leguminous shrub species in other regions. However, very few studies have evaluated the spatial heterogeneity of soil nutrients in C. intermedia shrub land, especially for alpine sandy land of the Tibet Plateau, with very high elevation and cold climate, lack of organic matter, nutrient and water. In this harsh environment, analysis the spatial distribution of soil nutrients and its impact factors are even more important, it will be helpful for understanding the ecological relationship between soil and environment [19]. Therefore, we performed a sampling campaign in C. intermedia plantation on sand dunes to test two general hypotheses that: (1) spatial heterogeneity of soil nutrients exists in the C. intermedia plantation on sand dunes of Gonghe Basin; (2) "fertile islands" are formed after establishment of C. intermedia plantations in alpine sandy land.

\section{Materials and Methods}

\section{Study Area}

This study was conducted in the desertification combating experimental site of the Qinghai Gonghe Desert Ecosystem Research Station $\left(99^{\circ} 45^{\prime}-100^{\circ} 30^{\prime} \mathrm{E}, 36^{\circ} 03^{\prime}-36^{\circ} 40^{\prime} \mathrm{N}\right.$ and altitude $2871 \mathrm{~m}$ ). The station is located in the Gonghe Basin of the northeastern Tibet Plateau. This station is a part of the Chinese Desert Ecosystem Research Network (CDERN) of the State Forestry Administration of P.R. China. The station was constructed by the Chinese Academy of Forestry and the Desertification Combating Station of Qinghai Province. No specific permissions were 
required to conduct research in this study site, and the field studies did not involve endangered or protected species. The climate in the study area is a plateau continental climate with a mean annual temperature of $2.4^{\circ} \mathrm{C}$, mean annual precipitation of $246.3 \mathrm{~mm}$ and mean annual potential evaporation of $1716.7 \mathrm{~mm}$. The mean annual frost-free period is only 91 days, and the total solar radiation is $6631.69 \mathrm{MJ} \cdot \mathrm{m}^{-2} \cdot \mathrm{y}^{-1}$. The mean annual number of windy days is 50.6 days (up to 97 days), and the mean annual number of sandstorm days is 20.7 days. The main wind directions are west and northwest, with a mean annual wind speed of $2.7 \mathrm{~m} \cdot \mathrm{s}^{-1}$; the maximum wind speed reaches $40 \mathrm{~m} \cdot \mathrm{s}^{-1}$. The zonal soils are chestnut soil and brown soil, while the azonal soils are aeolian, meadow and bog soils. In the research area, the main vegetation type is sand-fixing plantation, including tree species, e.g., Populus cathayana Rehd and Populus simonii Carr, and shrub species, e.g., C. intermedia, C. korshinskii Kom., Hippophae rhamnoides L., Salix cheilophila Schneid., and Salix psammophila C. Wang et Chang Y. Yang [7].

Caragana intermedia is the main species used for vegetation restoration on sand dunes in Gonghe Basin. Before C. intermedia were planted, straw checkerboards $(1 \mathrm{~m} \times 1 \mathrm{~m})$ were established on shifting sand dunes. This study was conducted on four fixed sand dunes, running in a northeast-southwest direction, on which C. intermedia was planted in May 2000. The belts of C. intermedia run parallel to the direction of the sand dunes, with $2.5 \mathrm{~m}$ between each row and 1 $\mathrm{m}$ between plants in each row. The mean length, width and height of sand dunes were approximately 90, 50 and $6 \mathrm{~m}$, respectively. The morphological characteristics of $10 \mathrm{C}$. intermedia plants were measured at each dune position; these characteristics included height (height of highest shoot), crown diameter (maximum diameter of the shrub canopy from Northeast-Southwest and Southeast-Northeast) and ground diameter (maximum diameter of the shrub shoots from Northeast-Southwest and Southeast-Northeast at ground level). The morphological characteristics of $C$. intermedia on the different slopes are shown in Table 1.

\section{Experiment Design and Soil Sampling}

Field work was conducted in June 2012. Three different topographical positions were selected on four sand dunes covered by C. intermedia: the middle of windward slopes, the middle of leeward slopes and dune tops. On each sand dune, four lines of $C$. intermedia were randomly selected as sampling sites. Soil samples were collected under shrubs and between shrubs with the depth of $0-5,5-10,10-20,20-30$ and $30-50 \mathrm{~cm}$. Four soil samples collected under shrubs from four $C$. intermedia lines on the same slope at the same depth were mixed into one soil sample; similarly, four soil samples collected between shrubs from four C. intermedia lines on the same slope at the same depth were mixed into one soil sample, and four sand dunes as four repetitions. The sampling location under shrubs was located $30 \mathrm{~cm}$ from the center of the shrub; the sampling location between shrubs was in the middle of two $C$. intermedia lines. The samples at $0-5 \mathrm{~cm}$ depth were collected by shovel, while deeper samples were collected using a 10-cm-diameter AMS soil auger. Soil samples were placed in zip-lock bags and air-dried for soil nutrient measurements.

Table 1. Morphological characteristics of $C$. intermedia plantation on different slopes on sand dunes.

\begin{tabular}{|c|c|c|c|c|c|}
\hline Slopes & Height (cm) & $\begin{array}{l}\text { Crown diameter }(\mathrm{cm}) \\
\text { Northeast-Southwest }\end{array}$ & Southeast-Northwest & $\begin{array}{l}\text { Ground diameter }(\mathrm{cm}) \\
\text { Northeast-Southwest }\end{array}$ & Southeast-Northwest \\
\hline Windward slopes & $121.90 \pm 6.00 \mathrm{a}$ & $105.60 \pm 6.88 a$ & $152.20 \pm 7.09 a$ & $24.80 \pm 1.70 b$ & $37.40 \pm 2.52 b$ \\
\hline Dune tops & $117.00 \pm 8.62 a$ & $110.50 \pm 9.89 a$ & $153.60 \pm 6.79 a$ & $22.00 \pm 1.29 a b$ & $28.50 \pm 0.86 a$ \\
\hline Leeward slopes & $117.80 \pm 3.26 a$ & $104.40 \pm 10.33 a$ & $140.90 \pm 5.50 a$ & $19.70 \pm 0.83 a$ & $24.40 \pm 0.78 a$ \\
\hline
\end{tabular}

Values are means of ten measurements \pm standard error. Different lowercase letters following values indicate a significant difference in morphological characteristics on different slopes, according to Duncan's multiple range test $(P<0.05)$.

doi:10.1371/journal.pone.0124456.t001 
A total of 120 soil samples were collected on sand dunes ( 3 positions $\times 2$ microsites $\times 5$ soil depths $\times 4$ replicates).

\section{Vegetation sampling}

Vegetation investigation was carried out in August 2012. Ten $1 \times 1 \mathrm{~m}^{2}$ quadrats were established randomly between shrubs for each slope position. At each selected quadrate, we assessed the number of herbaceous plant species and the height of each species. The herbaceous vegetation cover was estimated using the quadrats. Annual and perennial herbaceous vegetation increased after C. intermedia plantation establishment, the main species being Suaeda glauca (Bunge) Bunge, Leymus secalinus (Georgi) Tzvel and Artemisia sieversiana Ehrhart ex Willd. The nomenclature of main species included in this work follows Flora [6] and Flora Qinghaiica [20].

\section{Soil Laboratory Analysis}

Samples for soil nutrient measurement were hand-sieved through a 20-mesh sieve to remove roots and other debris. Half of each sample was put back into the zip-lock bag for available nutrient analyses, and the other half was sieved through a 100-mesh sieve for total nutrient and soil organic matter (SOM) analyses. All analyses were based on Physical and Chemical Analysis Methods of Soils [21]. SOM was measured by the $\mathrm{K}_{2} \mathrm{Cr}_{2} \mathrm{O}_{7}-\mathrm{H}_{2} \mathrm{SO}_{4}$ oxidation method. Total nitrogen (TN) and available nitrogen (AN) were measured by the Kjeldahl method. Total phosphorus (TP) was measured by the Mo-Sb colorimetric method, available phosphorus (AP) by the $\mathrm{NaHCO}_{3}$ extraction-Mo-Sb colorimetric method. Total potassium (TK) was measured by atomic absorption, whereas available potassium (AK) was measured by the ammonium acetate extraction atomic absorption method.

\section{Statistical Analysis}

All results are reported as the mean (four measurements) \pm standard error (SE). One-way ANOVA was used to compare morphological characteristics of $C$. intermedia among slopes, soil nutrient contents among treatments, and Duncan's multiple range tests was used to evaluate differences among the means. The $t$-test was used to show enrichment effects (the difference between under shrub and between shrub measurements). Correlation Analysis was used to analysis the correlation among soil nutrient indicators (at 0-5 cm), shrubs morphological characteristics and herbaceous coverage. SPSS 16.0 software was used for the above statistical analyses. The threshold of statistical significance was set at $P<0.05$ for all analyses. To identify differences in the soil nutrient contents under the shrub canopy (A) and between the shrub canopy (B), the enrichment ratio (E) was determined, where $\mathrm{E}=\mathrm{A} / \mathrm{B}[9,22]$. Redundancy Analysis (RDA) was used to evaluate the relationship between soil nutrients and environmental factors. We have two sets of variables, response variables and explanatory variables. The response variables are soil nutrients, and they are quantitative variables. The explanatory variables fall within two categories: quantitative variables (soil depth), and categorical variables (topography and microsite). All raw data were standardized $(y=\log (x+1))$, the significant of variables were tested 999 times by Monte Carlo, CANOCO 4.5 software was used for this statistical analyses.

\section{Results}

\section{The Distribution of SOM, TN, TP, TK, AN, AP and AK in C. intermedia Plantations on Sand Dunes}

The SOM content under shrubs for windward slopes and between shrubs for all slopes was highest at $0-5 \mathrm{~cm}$ and significantly decreased with greater soil depth $(P<0.05)$ (Table 2$)$. The 
Table 2. Spatial distribution of soil nutrients in C. intermedia plantation on sand dunes (mean $\pm \mathrm{SE}$ ).

\begin{tabular}{|c|c|c|c|c|c|c|c|}
\hline Index & $\begin{array}{l}\text { Soil depth } \\
\text { (cm) }\end{array}$ & $\begin{array}{l}\text { Under shrubs } \\
\text { Windward slopes }\end{array}$ & Dune tops & Leeward slopes & $\begin{array}{l}\text { Between shrubs } \\
\text { Windward slopes }\end{array}$ & Dune tops & Leeward slopes \\
\hline \multirow[t]{5}{*}{ SOM (g/kg) } & $0-5$ & $3.49 \pm 0.09 \mathrm{Aa}$ & $2.29 \pm 0.06 \mathrm{Ba}$ & $2.83 \pm 0.13 \mathrm{Ba}$ & $3.38 \pm 0.09 \mathrm{Aa}$ & $2.83 \pm 0.09 \mathrm{Ba}$ & $2.76 \pm 0.18 \mathrm{Ba}$ \\
\hline & $5-10$ & $3.04 \pm 0.17 \mathrm{Aab}$ & $2.85 \pm 0.08 \mathrm{Aa}$ & $2.58 \pm 0.25 \mathrm{Aa}$ & $2.80 \pm 0.23 \mathrm{Ab}$ & $2.56 \pm 0.11 \mathrm{Aab}$ & $2.46 \pm 0.21 \mathrm{Aa}$ \\
\hline & $10-20$ & $2.62 \pm 0.12 \mathrm{Abc}$ & $2.80 \pm 0.10 \mathrm{Aa}$ & $2.48 \pm 0.25 \mathrm{Aa}$ & $2.36 \pm 0.09 \mathrm{Abc}$ & $2.30 \pm 0.23 \mathrm{Aabc}$ & $2.31 \pm 0.21 \mathrm{Ab}$ \\
\hline & $20-30$ & $2.19 \pm 0.22 A c$ & $2.61 \pm 0.10 \mathrm{Aa}$ & $2.19 \pm 0.17 \mathrm{Aa}$ & $1.96 \pm 0.20$ Acd & $2.00 \pm 0.27 \mathrm{Abc}$ & $1.83 \pm 0.20 \mathrm{Abc}$ \\
\hline & $30-50$ & $1.66 \pm 0.17 \mathrm{Ad}$ & $2.23 \pm 0.31 \mathrm{Aa}$ & $2.02 \pm 0.18 \mathrm{Aa}$ & $1.57 \pm 0.13 \mathrm{Ad}$ & $1.84 \pm 0.27 \mathrm{Ac}$ & $1.44 \pm 0.05 \mathrm{Ac}$ \\
\hline \multirow[t]{5}{*}{$\mathrm{TN}(\mathbf{g} / \mathbf{k g})$} & $0-5$ & $0.55 \pm 0.02 \mathrm{Aa}$ & $0.40 \pm 0.03 \mathrm{Ba}$ & $0.43 \pm 0.03 \mathrm{Ba}$ & $0.39 \pm 0.02 A a$ & $0.35 \pm 0.02 \mathrm{Aa}$ & $0.40 \pm 0.03 \mathrm{Aa}$ \\
\hline & $5-10$ & $0.40 \pm 0.04 \mathrm{Ab}$ & $0.27 \pm 0.03 \mathrm{Bb}$ & $0.28 \pm 0.03 \mathrm{Bb}$ & $0.30 \pm 0.03 \mathrm{Ab}$ & $0.23 \pm 0.03 \mathrm{Ab}$ & $0.22 \pm 0.01 \mathrm{Ab}$ \\
\hline & $10-20$ & $0.37 \pm 0.03 \mathrm{Abc}$ & $0.24 \pm 0.01 \mathrm{Bb}$ & $0.27 \pm 0.03 \mathrm{Bb}$ & $0.27 \pm 0.02 A b$ & $0.21 \pm 0.02 A b$ & $0.22 \pm 0.02 \mathrm{Ab}$ \\
\hline & $20-30$ & $0.33 \pm 0.01 \mathrm{Abc}$ & $0.23 \pm 0.02 \mathrm{Bb}$ & $0.25 \pm 0.02 \mathrm{Bb}$ & $0.27 \pm 0.02 A b$ & $0.21 \pm 0.02 B b$ & $0.19 \pm 0.01 \mathrm{Bb}$ \\
\hline & $30-50$ & $0.32 \pm 0.01 \mathrm{Ac}$ & $0.22 \pm 0.01 \mathrm{Bb}$ & $0.25 \pm 0.02 \mathrm{Bb}$ & $0.26 \pm 0.01 \mathrm{Ab}$ & $0.18 \pm 0.01 \mathrm{Bb}$ & $0.19 \pm 0.01 \mathrm{Bb}$ \\
\hline \multirow[t]{5}{*}{ TP $(\mathbf{g} / \mathbf{k g})$} & $0-5$ & $0.44 \pm 0.03 \mathrm{Aa}$ & $0.23 \pm 0.02 \mathrm{Ba}$ & $0.33 \pm 0.05 \mathrm{Ba}$ & $0.33 \pm 0.04 \mathrm{Aa}$ & $0.21 \pm 0.01 \mathrm{Ba}$ & $0.25 \pm 0.01 \mathrm{Ba}$ \\
\hline & $5-10$ & $0.36 \pm 0.03 A a b$ & $0.24 \pm 0.01 \mathrm{Ba}$ & $0.28 \pm 0.03 \mathrm{Ba}$ & $0.30 \pm 0.03 \mathrm{Aa}$ & $0.20 \pm 0.01 \mathrm{Ba}$ & $0.23 \pm 0.02 \mathrm{Ba}$ \\
\hline & $10-20$ & $0.35 \pm 0.04 \mathrm{Aab}$ & $0.22 \pm 0.02 \mathrm{Ba}$ & $0.27 \pm 0.03 \mathrm{ABa}$ & $0.32 \pm 0.01 \mathrm{Aa}$ & $0.21 \pm 0.01 \mathrm{Ba}$ & $0.22 \pm 0.03 \mathrm{Ba}$ \\
\hline & $20-30$ & $0.32 \pm 0.01 \mathrm{Abc}$ & $0.24 \pm 0.03 \mathrm{Ba}$ & $0.23 \pm 0.02 \mathrm{Ba}$ & $0.30 \pm 0.02 \mathrm{Aa}$ & $0.21 \pm 0.02 \mathrm{Aa}$ & $0.22 \pm 0.03 \mathrm{Aa}$ \\
\hline & $30-50$ & $0.25 \pm 0.01 \mathrm{Ac}$ & $0.22 \pm 0.02 \mathrm{Ba}$ & $0.21 \pm 0.01 \mathrm{Aa}$ & $0.25 \pm 0.04 \mathrm{Aa}$ & $0.20 \pm 0.01 \mathrm{Aa}$ & $0.23 \pm 0.02 \mathrm{Aa}$ \\
\hline \multirow[t]{5}{*}{ TK (g/kg) } & $0-5$ & $14.82 \pm 0.16 \mathrm{Aa}$ & $12.65 \pm 0.71 \mathrm{Ba}$ & $13.75 \pm 0.10 \mathrm{ABa}$ & $13.25 \pm 0.33 \mathrm{Aa}$ & $11.84 \pm 0.39 \mathrm{Ba}$ & $12.70 \pm 0.25 \mathrm{ABa}$ \\
\hline & $5-10$ & $14.57 \pm 0.12 \mathrm{Aa}$ & $12.59 \pm 0.63 \mathrm{Ba}$ & $12.68 \pm 0.13 \mathrm{Ba}$ & $11.54 \pm 1.19 \mathrm{Aa}$ & $10.54 \pm 0.84 \mathrm{Aa}$ & $11.33 \pm 0.89 \mathrm{Aa}$ \\
\hline & $10-20$ & $14.76 \pm 0.09 \mathrm{Aa}$ & $12.46 \pm 0.37 \mathrm{Ba}$ & $11.92 \pm 0.65 \mathrm{Ba}$ & $11.30 \pm 1.17 \mathrm{Aa}$ & $11.30 \pm 0.56 \mathrm{Aa}$ & $12.38 \pm 0.44 \mathrm{Aa}$ \\
\hline & $20-30$ & $14.70 \pm 0.12 \mathrm{Aa}$ & $11.55 \pm 0.64 \mathrm{Ba}$ & $12.21 \pm 0.24 \mathrm{Ba}$ & $12.19 \pm 0.32 \mathrm{Aa}$ & $12.57 \pm 0.46 \mathrm{Aa}$ & $12.88 \pm 0.52 \mathrm{Aa}$ \\
\hline & $30-50$ & $14.63 \pm 0.25 \mathrm{Aa}$ & $11.83 \pm 0.36 \mathrm{Ba}$ & $12.38 \pm 0.69 \mathrm{Ba}$ & $12.31 \pm 0.56 \mathrm{Aa}$ & $12.08 \pm 0.50 \mathrm{Aa}$ & $13.09 \pm 0.05 \mathrm{Aa}$ \\
\hline \multirow[t]{5}{*}{ AN $(\mathrm{mg} / \mathrm{kg})$} & $0-5$ & $114.59 \pm 1.47 \mathrm{Aa}$ & $106.05 \pm 4.08 \mathrm{Aa}$ & $108.12 \pm 3.35 \mathrm{Aa}$ & $95.45 \pm 4.08 \mathrm{Aa}$ & $77.77 \pm 4.08 \mathrm{Ba}$ & $79.22 \pm 3.45 \mathrm{Ba}$ \\
\hline & $5-10$ & $98.98 \pm 5.77 \mathrm{Aa}$ & $91.91 \pm 4.08 \mathrm{Aa}$ & $91.91 \pm 4.08 \mathrm{Aab}$ & $88.38 \pm 3.54 \mathrm{Aa}$ & $40.12 \pm 13.66 \mathrm{Bb}$ & $57.79 \pm 7.21 \mathrm{Bb}$ \\
\hline & $10-20$ & $72.60 \pm 10.07 \mathrm{Ab}$ & $65.46 \pm 8.78 \mathrm{Ab}$ & $71.49 \pm 12.11 \mathrm{Abc}$ & $74.24 \pm 3.54 \mathrm{Ab}$ & $52.17 \pm 9.03 \mathrm{Bb}$ & $57.57 \pm 4.64 \mathrm{ABb}$ \\
\hline & $20-30$ & $62.04 \pm 9.84 \mathrm{Ab}$ & $60.73 \pm 6.98 \mathrm{Ab}$ & $65.75 \pm 3.21 \mathrm{Ac}$ & $74.24 \pm 3.54 \mathrm{Ab}$ & $48.28 \pm 8.95 \mathrm{Ab}$ & $61.57 \pm 5.54 \mathrm{Ab}$ \\
\hline & $30-50$ & $56.08 \pm 9.86 \mathrm{Ab}$ & $56.70 \pm 9.98 \mathrm{Ab}$ & $50.63 \pm 7.56 \mathrm{Ac}$ & $70.70 \pm 5.77 \mathrm{Ab}$ & $42.38 \pm 8.35 \mathrm{Bb}$ & $62.86 \pm 3.36 \mathrm{Ab}$ \\
\hline \multirow[t]{5}{*}{ AP $(\mathrm{mg} / \mathrm{kg})$} & $0-5$ & $5.29 \pm 0.15 \mathrm{Aa}$ & $4.53 \pm 0.15 \mathrm{Ba}$ & $4.32 \pm 0.15 \mathrm{Ba}$ & $4.61 \pm 0.16 \mathrm{Aa}$ & $3.93 \pm 0.11 \mathrm{Ba}$ & $3.93 \pm 0.15 \mathrm{Ba}$ \\
\hline & $5-10$ & $3.95 \pm 0.07 \mathrm{Ab}$ & $3.30 \pm 0.15 \mathrm{Bb}$ & $3.55 \pm 0.10 \mathrm{Bb}$ & $3.72 \pm 0.07 \mathrm{Ab}$ & $3.08 \pm 0.04 \mathrm{Bb}$ & $2.91 \pm 0.11 \mathrm{Bb}$ \\
\hline & $10-20$ & $3.68 \pm 0.04 \mathrm{Ab}$ & $2.91 \pm 0.13 \mathrm{Cbc}$ & $3.30 \pm 0.11 \mathrm{Bb}$ & $3.64 \pm 0.08 \mathrm{Ab}$ & $2.87 \pm 0.21 \mathrm{Bb}$ & $2.79 \pm 0.11 \mathrm{Bb}$ \\
\hline & $20-30$ & $3.72 \pm 0.14 \mathrm{Ab}$ & $3.00 \pm 0.16 \mathrm{Bbc}$ & $3.21 \pm 0.12 \mathrm{Bb}$ & $3.51 \pm 0.08 \mathrm{Ab}$ & $2.70 \pm 0.07 \mathrm{Bb}$ & $2.83 \pm 0.23 \mathrm{Bb}$ \\
\hline & $30-50$ & $3.72 \pm 0.12 \mathrm{Ab}$ & $2.83 \pm 0.13 \mathrm{Cc}$ & $3.30 \pm 0.05 \mathrm{Bb}$ & $3.64 \pm 0.05 \mathrm{Ab}$ & $2.74 \pm 0.15 \mathrm{Bb}$ & $2.91 \pm 0.11 \mathrm{Bb}$ \\
\hline \multirow[t]{5}{*}{ AK (mg/kg) } & $0-5$ & $104.69 \pm 0.82 \mathrm{Aa}$ & $102.23 \pm 0.53 \mathrm{Aa}$ & $103.84 \pm 0.60 \mathrm{Aa}$ & $95.69 \pm 1.03 \mathrm{Aa}$ & $94.66 \pm 4.95 \mathrm{Aa}$ & $94.13 \pm 2.94 \mathrm{Aa}$ \\
\hline & $5-10$ & $100.31 \pm 1.81 \mathrm{Ab}$ & $98.26 \pm 2.37 \mathrm{Aa}$ & $99.94 \pm 1.44 \mathrm{Aab}$ & $91.98 \pm 1.67 \mathrm{Aa}$ & $92.44 \pm 3.56 \mathrm{Aa}$ & $92.99 \pm 1.31 \mathrm{Aa}$ \\
\hline & $10-20$ & $91.64 \pm 1.13 \mathrm{Ac}$ & $96.51 \pm 3.94 \mathrm{Aa}$ & $94.74 \pm 2.50 \mathrm{Abc}$ & $90.72 \pm 2.43 \mathrm{Aa}$ & $89.97 \pm 1.80 \mathrm{Aa}$ & $91.16 \pm 1.21 \mathrm{Aab}$ \\
\hline & $20-30$ & $89.17 \pm 1.59 \mathrm{Acd}$ & $89.79 \pm 0.38 \mathrm{Ab}$ & $89.52 \pm 2.53 \mathrm{Acd}$ & $90.78 \pm 2.27 \mathrm{Aa}$ & $87.84 \pm 1.29 \mathrm{Aa}$ & $86.76 \pm 1.66 \mathrm{Abc}$ \\
\hline & $30-50$ & $86.88 \pm 0.91 \mathrm{Ad}$ & $89.05 \pm 0.77 \mathrm{Ab}$ & $87.51 \pm 1.52 \mathrm{Ad}$ & $88.05 \pm 1.07 \mathrm{Aa}$ & $88.07 \pm 0.67 \mathrm{Aa}$ & $84.69 \pm 1.07 \mathrm{Ac}$ \\
\hline
\end{tabular}

Notes: Different uppercase letters following values indicate a significant difference in soil nutrient contents at different dune positions; different lowercase letters following values indicate a significant difference in soil nutrient contents at different soil depths, according to Duncan's multiple range test $(\mathrm{P}<0.05)$, $\mathrm{n}=4$.

doi:10.1371/journal.pone.0124456.t002

$\mathrm{TN}, \mathrm{AN}$ and $\mathrm{AP}$ content under and between shrubs for all slopes at the $0-5 \mathrm{~cm}$ depth was significantly higher than at other depths $(P<0.05)$.

The SOM content under and between shrubs at $0-5 \mathrm{~cm}$ depth was significantly higher in windward slopes than in dune tops and leeward slopes $(P<0.05)$. The TN content under shrubs at all soil depths, AN content between shrubs at the $0-5$ and 5-10 $\mathrm{cm}$ depths was significantly higher in windward slopes than in dune tops and leeward slopes $(P<0.05)$. The TP content 
under and between shrubs at $0-5$ and $5-10 \mathrm{~cm}$ depth, AP content at all depths was significantly higher in windward slopes than in dune tops and leeward slopes $(P<0.05)$. The TK content under and between shrubs at $0-5 \mathrm{~cm}$ was significantly higher in windward slopes than in dune tops $(P<0.05)$.

\section{Effects of Shrubs on Soil Nutrients Enrichment for Different Slopes}

The $t$-test analysis showed that on windward slopes, the levels of TN, TP and TK were significantly higher under shrubs than between shrubs $(P<0.05)$ (Table 3$)$. On dune tops, SOM, TP, $\mathrm{AN}$ and AK levels were significantly higher under shrubs than between shrubs $(P<0.05)$. On leeward slopes, levels of AN, AP and AK were significantly higher under shrubs than between shrubs $(P<0.05)$. For the contents of SOM, TN, TP, TK, AP and AK of all slopes, E was $>1.00$. The E for AN content on dune tops and leeward slopes was also $>1.00$. The E of TN content on windward (1.33) and leeward slopes (1.26) was higher than for other nutrients. The E of AN content on dune tops (1.62) was higher than for other nutrients.

\section{Relationship between soil nutrients and environmental factors}

Redundancy analysis (RDA) visualizes correlations of soil nutrients with environmental factors (Fig 1). A total of $86.7 \%$ of the cumulative variance of the soil-environment relationship was represented by the first two axes. This result indicated a strong association between soil nutrients and the measured environmental factors. Samples in the positive part of axis 1 had higher depths, those in the negative part were located in the upper soil layers. Therefore, axis 1 represented soil depth, and it was the most important driver of soil nutrients in the study. Axis 2 was in the same direction with topography (with the direction of windward slope-leeward slopedune top) and microsites (with the direction of under shrubs to between shrubs), therefore, axis 2 represented topography and microsites. Soil nutrients increased towards the negative

Table 3. Enrichment ratio (E) of SOM (soil organic matter), TN (total nitrogen), TP (total phosphorus), TK (total potassium), AN (available nitrogen), AP (available phosphorus) and AK (available potassium) at different dune positions.

\begin{tabular}{|c|c|c|c|c|c|c|c|}
\hline \multirow[t]{2}{*}{ Variation } & & \multicolumn{2}{|l|}{ Windward slopes } & \multicolumn{2}{|l|}{ Dune tops } & \multicolumn{2}{|l|}{ Leeward slopes } \\
\hline & & & BS & & BS & & BS \\
\hline \multirow[t]{2}{*}{ SOM (g/kg) } & Mean & $2.60 \pm 0.16 a$ & $2.42 \pm 0.16 a$ & $2.68 \pm 0.09 a$ & $2.30 \pm 0.0 .12 b$ & $2.42 \pm 0.10 \mathrm{a}$ & $2.16 \pm 0.13 a$ \\
\hline & $E$ & 1.09 & & 1.25 & & 1.16 & \\
\hline \multirow[t]{2}{*}{$\mathrm{TN}(\mathbf{g} / \mathbf{k g})$} & Mean & $0.39 \pm 0.02 a$ & $0.30 \pm 0.01 b$ & $0.27 \pm 0.02 a$ & $0.23 \pm 0.02 a$ & $0.30 \pm 0.02 a$ & $0.24 \pm 0.02 a$ \\
\hline & $E$ & 1.33 & & 1.33 & & 1.26 & \\
\hline \multirow[t]{2}{*}{ TP $(\mathbf{g} / \mathbf{k g})$} & Mean & $0.34 \pm 0.02 a$ & $0.30 \pm 0.01 b$ & $0.23 \pm 0.01 a$ & $0.21 \pm 0.01 b$ & $0.27 \pm 0.01 a$ & $0.23 \pm 0.01 a$ \\
\hline & $E$ & 1.19 & & 1.13 & & 1.19 & \\
\hline \multirow[t]{2}{*}{ TK (g/kg) } & Mean & $14.70 \pm 0.07 a$ & $12.52 \pm 0.42 b$ & $12.22 \pm 0.29 a$ & $12.67 \pm 0.30 a$ & $12.59 \pm 0.18 a$ & $12.47 \pm 0.23 a$ \\
\hline & $E$ & 1.20 & & 1.06 & & 1.01 & \\
\hline \multirow[t]{2}{*}{ AN $(\mathrm{mg} / \mathrm{kg})$} & Mean & $80.85 \pm 6.07 a$ & $80.60 \pm 2.73 a$ & $76.17 \pm 5.28 a$ & $52.14 \pm 4.31 b$ & $77.58 \pm 5.40 a$ & $63.80 \pm 2.67 \mathrm{~b}$ \\
\hline & $E$ & 0.99 & & 1.62 & & 1.25 & \\
\hline \multirow[t]{2}{*}{ AP (mg/kg) } & Mean & $4.07 \pm 0.15 a$ & $3.82 \pm 0.10 a$ & $3.31 \pm 0.15 a$ & $3.07 \pm 0.12 a$ & $3.53 \pm 0.10 a$ & $3.07 \pm 0.12 b$ \\
\hline & $E$ & 1.05 & & 1.07 & & 1.16 & \\
\hline \multirow[t]{2}{*}{ AK (mg/kg) } & Mean & $95.24 \pm 1.92 a$ & $91.44 \pm 0.91 a$ & $95.17 \pm 1.42 a$ & $90.60 \pm 1.31 b$ & $95.11 \pm 1.59 a$ & $89.95 \pm 1.09 \mathrm{~b}$ \\
\hline & $E$ & 1.03 & & 1.05 & & 1.06 & \\
\hline
\end{tabular}

Notes: US, under shrubs; BS, between shrubs. The $t$-test was used to show enrichment effect (the difference between US and BS). Different lowercase letters following values indicate a significant difference in SOM, TN, TP, TK, AN, AP and AK under and between shrubs, according to $t$-test $(P<0.05)$.

doi:10.1371/journal.pone.0124456.t003 


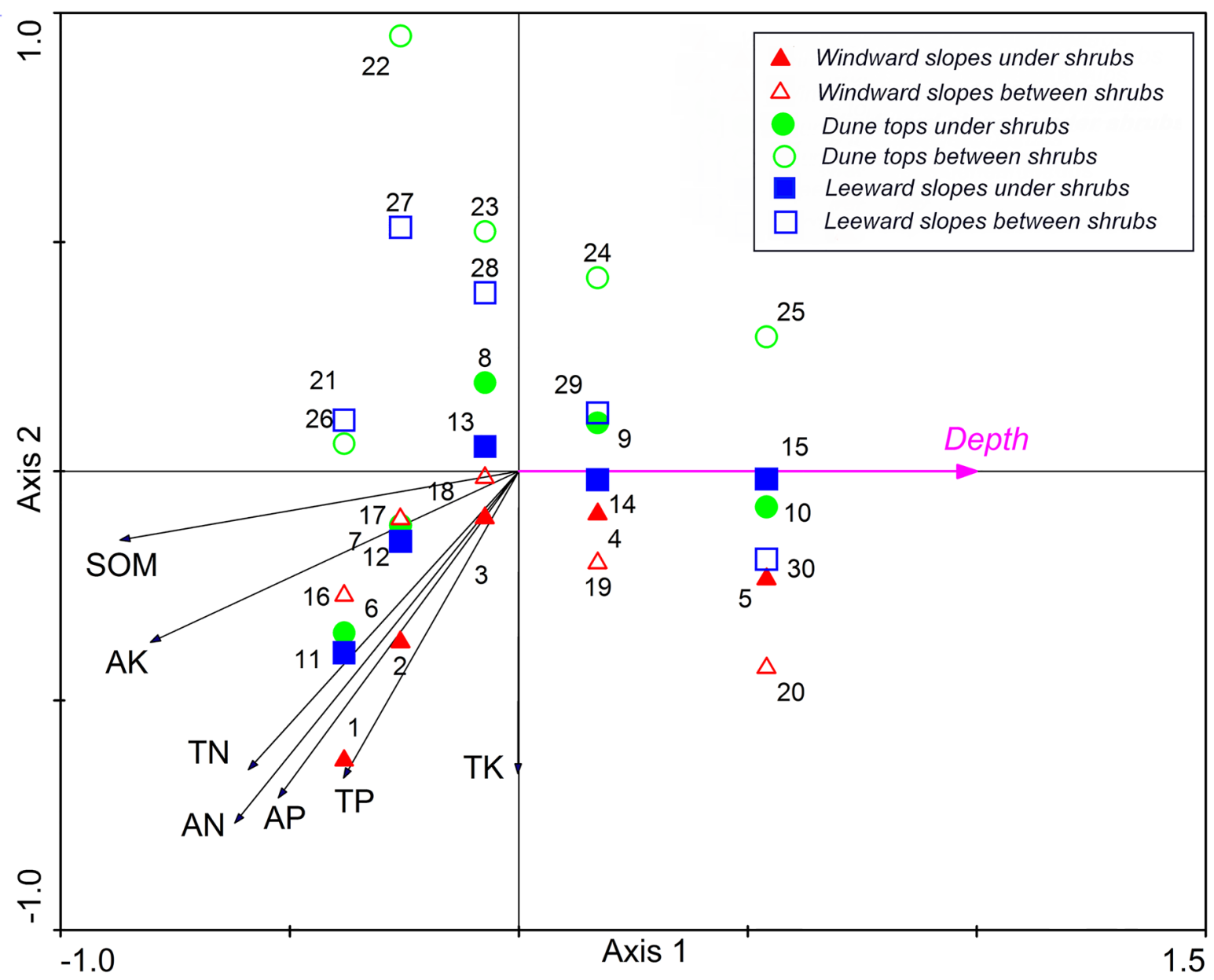

Fig 1. RDA two-dimensional ordination diagram of the first two axes showing the correlation of soil nutrients and environmental factors.

doi:10.1371/journal.pone.0124456.g001

part of axis 1 and 2, suggesting that nutrients increased in the upper soil, windward slope and under shrubs.

There was a convergence towards more soil nutrients in all topography positions and microsites at shallower soil layers. Windward slopes with the highest soil nutrients level, followed by leeward slopes, the dune tops with the lowest soil nutrients level. The difference of soil nutrients level between topography positions was more marked in between shrubs. In the dune tops, the soil nutrients level under shrubs was higher than between shrubs. The difference of soil nutrients level between "under shrubs" and "between shrubs" for dune tops was more marked than other topography positions. In the leeward slopes, the soil nutrients level under shrubs was higher than between shrubs except for 30-50 cm depth. Contrary to the other topography positions, windward slopes had less difference of soil nutrients level between "under shrubs" and "between shrubs". All of these mean that "fertile islands" were formed, especially for shallow soil layers, and the "fertile islands" were more marked on lower soil nutrients level topography positions, while it decreased towards higher soil nutrients level topography positions.

\section{Discussion}

Low levels of soil nutrients are a major feature in arid and semi-arid ecosystems. The fixation of shifting sand dunes lies primarily in the restoration of vegetation and improvement of soil 
fertility [23]. The shrubs are the main species and they are very important in the ecological function of arid and semi-arid ecosystems. Some shrub species play crucial roles in preventing desertification and in restoration of degraded arid lands [24]. At the same time, the presence of shrubs strongly influences soil nutrients distribution [25].

This study showed that spatial heterogeneity of soil nutrients was existed in C. intermedia plantation on sand dunes. Depth was the most important environment factor influencing soil nutrient distribution on sand dunes (Fig 1), more soil nutrients (SOC, TN, TP, AN, AP and AK) accumulated on surface soil $(0-5 \mathrm{~cm})$ and decreased with soil depth (Table 2), indicating that soil nutrients had undergone surface aggregation. The possible reason for this phenomenon is that litter and windblown fine materials were trapped by shrubs and accumulated on surface soil [10], their nutrients returned to soil via microbial decomposition [22], which leads to higher nutrient level. The studies about C. microphylla plantation on sand dunes have also shown that soil nutrients were higher on surface soil than in deeper layer soil [9].

Topography is an important factor to consider in the process of vegetation restoration, as it affects soil moisture, soil temperature and air flow, there by affecting the spatial heterogeneity of soil properties [26-28]. Our study showed that more soil nutrients accumulated on windward slopes, especially on surface soil (Table 2). To analyze this phenomenon, we did a correlation analysis among surface soil nutrients, shrubs morphological characteristics and herbaceous coverage (Table 4 ). The herbaceous coverage was significantly positive correlated with SOM, TP, AP $(P<0.01)$, TN, TK $(P<0.05)$. The coverage of herbaceous vegetation for windward slopes was $30.3 \%$, much higher than dune tops (14.7\%) and leeward slopes (18.8\%) (Table 5). The development of herbaceous plants on sand dunes was an important part of net primary productivity, and the plants' rapid growth and death were important ways by which soil nutrients accumulated [29-30]. Therefore, the higher coverage of herbaceous vegetation is a possible reason for more soil nutrients accumulated on windward slopes. The ground diameter of $C$. intermedia was also significantly positive correlated with SOM, TN, TK $(P<0.01)$, AN,

Table 4. Pearson's correlation among soil nutrient indicators (at $0-5 \mathrm{~cm}$ ), morphological characteristics of shrub and herbaceous coverage.

\begin{tabular}{|c|c|c|c|c|c|c|c|c|c|c|c|c|c|}
\hline Parameters & SOM & TN & TP & TK & AN & AP & AK & $\mathbf{H}$ & C1 & C2 & G1 & G2 & $\mathrm{H}-\mathrm{C}$ \\
\hline SOM & 1.00 & & & & & & & & & & & & \\
\hline TN & $0.77^{* *}$ & 1.00 & & & & & & & & & & & \\
\hline TP & 0.44 & $0.62^{*}$ & 1.00 & & & & & & & & & & \\
\hline TK & 0.52 & 0.48 & $0.58^{*}$ & 1.00 & & & & & & & & & \\
\hline AN & 0.49 & $0.66^{*}$ & 0.38 & $0.68 *$ & 1.00 & & & & & & & & \\
\hline AP & $0.80 * *$ & $0.59 *$ & 0.43 & 0.48 & 0.44 & 1.00 & & & & & & & \\
\hline AK & 0.41 & $0.72 * *$ & 0.48 & $0.60 *$ & 0.49 & 0.45 & 1.00 & & & & & & \\
\hline H & 0.178 & 0.132 & -0.11 & 0.38 & 0.55 & -0.20 & -0.03 & 1.00 & & & & & \\
\hline C1 & -0.28 & -0.31 & -0.38 & -0.20 & -0.21 & -0.46 & -0.26 & 0.39 & 1.00 & & & & \\
\hline C2 & -0.02 & -0.04 & -0.17 & -0.33 & -0.01 & -0.27 & -0.48 & 0.26 & 0.19 & 1.00 & & & \\
\hline G1 & 0.57 & 0.48 & 0.42 & $0.76 * *$ & $0.64 *$ & 0.53 & 0.38 & 0.46 & 0.23 & -0.14 & 1.00 & & \\
\hline G2 & $0.81 * *$ & $0.73^{* *}$ & 0.53 & 0.46 & 0.48 & $0.70^{*}$ & 0.40 & 0.18 & -0.10 & -0.24 & $0.67^{*}$ & 1.00 & \\
\hline $\mathrm{H}-\mathrm{C}$ & $0.83 * *$ & $0.69 *$ & $0.71^{* *}$ & $0.67^{*}$ & 0.39 & $0.79 * *$ & 0.51 & -0.09 & -0.39 & -0.14 & 0.55 & $0.72 * *$ & 1.00 \\
\hline
\end{tabular}

$\mathrm{H}$, shrubs height; $\mathrm{C} 1$, shrubs crown diameter with the direction of Northeast-Southwest; C2, shrubs crown diameter with the direction of SoutheastNorthwest; G1, shrubs ground diameter with the direction of Northeast—Southwest; G2, shrubs ground diameter with the direction of SoutheastNorthwest; $\mathrm{H}-\mathrm{C}$, herbaceous coverage.

*Correlation significant at the 0.05 level (2-tailed).

**Correlation significant at the 0.01 level (2-tailed).

doi:10.1371/journal.pone.0124456.t004 
Table 5. Distribution of herbaceous in C. intermedia plantation on sand dunes.

\begin{tabular}{|c|c|c|c|c|c|c|c|c|c|c|}
\hline \multirow[t]{2}{*}{ Species name } & \multirow[t]{2}{*}{ Life form } & \multicolumn{3}{|c|}{ Windward slopes } & \multicolumn{3}{|c|}{ Dune tops } & \multicolumn{3}{|c|}{ Leeward slopes } \\
\hline & & $\mathbf{N}$ & $\mathrm{H}(\mathbf{c m})$ & $\mathrm{F} \%$ & $\mathbf{N}$ & $\mathbf{H}(\mathbf{c m})$ & $\mathbf{F} \%$ & $\mathbf{N}$ & $\mathrm{H}(\mathrm{cm})$ & $\mathbf{F} \%$ \\
\hline Suaeda glauca (Bunge) Bunge & AF & 49.8 & 8 & 90 & 107 & 7.9 & 100 & 39.7 & 9 & 80 \\
\hline Leymus secalinus (Georgi) Tzvel. & $P G$ & 75.2 & 46.4 & 100 & 12.6 & 29.6 & 70 & 58.2 & 47.2 & 100 \\
\hline Artemisia sieversiana Ehrhart ex Willd. & AF & 54.4 & 25.1 & 80 & 2.7 & 18.7 & 30 & 33.7 & 22.7 & 70 \\
\hline Salsola collina A. J. Li & AF & 6.8 & 8.6 & 80 & 5.4 & 10.2 & 60 & 13.8 & 11.4 & 50 \\
\hline Artemisia desertorum Spreng. & PS & 2.9 & 32.2 & 50 & 1.3 & 31.2 & 50 & 0.1 & 36 & 10 \\
\hline Plantago minuta Pall. & AF & 1.2 & 8.7 & 30 & 1.7 & 5.7 & 60 & 0.1 & 8 & 10 \\
\hline Lappula myosotis v. Wolf, Gen & AF & 0.9 & 11.7 & 30 & 0.8 & 11.5 & 20 & 4.8 & 18 & 40 \\
\hline Heteropappus altaicus (Willd.) Novopokr. & PF & 0.8 & 37.5 & 40 & 0.4 & 23.7 & 30 & & & \\
\hline Glycyrrhiza uralensis Fisch. & PL & 0.2 & 32 & 10 & & & & & & \\
\hline Sonchus oleraceus Linn. & PF & & & & & & & 1.5 & 34.5 & 20 \\
\hline Convolvulus arvensis Linn. & PF & 0.9 & 17 & 10 & & & & & & \\
\hline Lepidium apetalum Willd & AF & 0.2 & 16 & 10 & & & & & & \\
\hline Setaria viridis (Linn.) Beauv. & $A G$ & & & & 0.7 & 8 & 10 & 0.1 & 6 & 10 \\
\hline Achnatherum splendens (Trin.) Nevski & $P G$ & & & & & & & 0.1 & 119 & 10 \\
\hline Peganum multisectum) (Maxiam.) Bobr. & PF & & & & & & & 0.1 & 28 & 10 \\
\hline Total number of individuals & & 193.3 & & & 132.6 & & & 152.2 & & \\
\hline Total number of species & & 11 & & & 9 & & & 11 & & \\
\hline Coverage (\%) & & 30.3 & & & 14.7 & & & 18.8 & & \\
\hline
\end{tabular}

$\mathrm{N}$, numbers of individuals; $\mathrm{H}$, height of species; F\%, frequency; $\mathrm{AF}$, annual forbs; AG, annual grass; PF, perennial forbs; PG, perennial grass; PL, perennial legume; PS, perennial shrub.

AP $(P<0.05)$ (Table 4). The ground diameter of $C$. intermedia on windward slopes was larger than on dune tops and leeward slopes (Table 1). Larger ground diameters may be related to its larger root system, which results in a high level of nitrogen fixation and even more soil microbes, and it could be conductive to the soil amelioration. Other studies also showed that the sediment amount and fine materials were positively and significantly correlated with shrubs ground shoots number and shoots diameter [31]. In addition, in alpine sandy lands with a semi-arid climate, wind erosion was changed by topography and plantation. Wind speed was reduced when it went through the plantations [23], maybe more wind erosion materials and litter were trapped and concentrated under the shrubs when sand flow went through windward slopes. When the impaired sand flow reached the dune tops and leeward slopes, less wind erosion materials, dust and litter were trapped by $C$. intermedia, and this may be another reason for more soil nutrients distributed on windward slopes, however, further study is needed for clarification.

More soil nutrients concentrated under shrubs than between shrubs on sand dunes (Table 3), soil nutrients were obviously enriched by C. intermedia, and a typical "fertile islands" were formed in this semi-arid region, especially for shallow soil layers. This is similar to other plantations in Horqin Sandy Land and Loess Plateau [22, 32]. There are several possible reasons for the formation of "fertile islands" in C. intermedia plantations. One of the possible reasons is that shrubs reduce wind velocity and soil erosion [31], trap windblown fine materials; and thus deposition of dust concentrates nutrients below their canopy [33], which creates "fertile islands" in a low-nutrient matrix [34]. Another possible reason is that rainfall containing atmospheric dust was intercepted by the canopy, and the nutrients in the dust were combined with leaf secretions, leading to an increase in soil nutrients [35]. In addition, root exudates and 
the deposition of dead roots in the rhizosphere may increase soil nutrient levels. For example, SOM, TN, AN and AP contents of C. microphylla and Artemisia halodendron were all higher in the rhizosphere than non-rhizosphere soil in Horqin Sandy Land [36]. The E ratio for TN on windward and leeward slopes, as well as the $\mathrm{E}$ ratio for AN on dune tops, was higher than for other nutrients, most likely because $C$. intermedia is a leguminous shrub and has a large number of rhizobia with high nitrogenase activity in the root systems, which can fix free nitrogen in the air [32]. Similarly, the E for TN was higher than that for TP and TK in C. microphylla in Horqin Sandy Land [9].

\section{Conclusions}

The results of this study showed that more soil nutrients accumulated on surface soil $(0-5 \mathrm{~cm})$ and decreased with greater soil depth, more soil nutrients distributed on windward slopes, and more soil nutrients concentrated under shrubs. These results indicate that spatial heterogeneity of soil nutrients was existed in C. intermedia plantation on sand dunes in Gonghe Basin, and soil "fertile islands" were formed under shrubs, especially for shallow soil layers. Understanding the spatial heterogeneity of soil nutrients in C. intermedia plantation on sand dunes was significant for the establishment and management of shrub plantations in alpine sandy land.

\section{Acknowledgments}

We are very thankful to Yang Yu, Haitao Liu and staff at Sand Control Experimental Station of Qinghai Province for providing field assistance. We are very grateful to Prof. M. Teresa Sebastià for constructive comments and guidance significantly improving the paper. We are also very thankful to anonymous reviewer and editors for their very valuable comments and suggestions on the manuscript.

\section{Author Contributions}

Conceived and designed the experiments: ZQJ QXL. Performed the experiments: QXL YJZ DFY XBZ. Analyzed the data: QXL ZQJ YSW. Contributed reagents/materials/analysis tools: ZQJ. Wrote the paper: QXL. Participated in the modification of manuscript: HL.

\section{References}

1. Wang XP, Li XR, Xiao HL, Pan YX. Evolutionary characteristics of the artificially revegetated shrub ecosystem in Tengger Desert, northern China. Ecol Res. 2006; 21(3): 415-424.

2. Reynolds JF, Stafford Smith DM, Lambin EF, Turner BL, Mortimore M, Batterbury SPJ, et al. Global desertification: building a science for dryland development. Science. 2007; 316: 847-851. PMID: 17495163

3. Su YZ, Zhang TH, Li YL, Wang F. Changes in soil properties after establishment of Artemisia halodendron and Caragana microphylla on shifting sand dunes in semiarid Horqin Sandy Land, northern China. Environ Manage. 2005; 36(2): 272-281. PMID: 16025199

4. Li XR, Xiao HL, Zhang JG, Wang XP. Long-Term Ecosystem Effects of Sand-Binding Vegetation in the Tengger Desert, Northern China. Restor Ecol. 2004; 12: 376-390.

5. Zhang DS, Gao SY, Shi MY, Ha S, Yan P, Lu RJ. Sandy Desertification and It's Control in the Qinghai Plateau. Beijing: Science Press; 2009. pp. 39. (in Chinese).

6. Fu KJ, He YQ, Ding CS, Liu YX, Li PQ. Flora. Beijing: Science Press; 1993. (in Chinese).

7. Jia ZQ, Zhu YJ, Liu LY. Different water use strategies of juvenile and adult Caragana intermedia plantations in the Gonghe Basin, Tibet Plateau. PLoS One. 2012; 7(9): 1-6.

8. Gei MG, Powers JS. Do legumes and non-legumes tree species affect soil properties in unmanaged forests and plantations in Costa Rican dry forests? Soil Biol Biochem. 2013; 57: 264-272.

9. Pugnaire FI, Haase P, Puigdefábregas J, Cueto M, Clark SC, Incoll LD. Facilitation and succession under the canopy of a leguminous shrub, Retama sphaerocarpa, in a semi-arid environment in southeast Spain. OIKOS. 1996; 76: 455-464. 
10. Pugnaire FI, Armas $C$, Valladares F. Soil as a mediator in plant-plant interactions in a semi-arid community. J VEG SCI. 2004; 15: 85-92.

11. Moro MJ, Pugnaire FI, Haase P, Puigdefábregas J. Effect of the canopy of Retama sphaerocarpa on its understory in a semiarid environment. Funct Ecol. 1997; 11: 425-431.

12. Zhang PJ, Yang J, Zhao LQ, Bao SRL, Song BY. Effect of Caragana tibetica nebkhas on sand entrapment and fertile islands in steppe-desert ecotones on the Inner Mongolia Plateau, China. Plant Soil. 2011; 347(1-2): 79-90.

13. Dong XW, Zhang XK, Bao XL, Wang JK. Spatial distribution of soil nutrients after the establishment of sand-fixing shrubs on sand dune. Plant Soil Environ. 2009; 55(7): 288-294.

14. Cao $\mathrm{CY}$, Jiang SY, Zhang Y, Zhang FX, Han XS. Spatial variability of soil nutrients and microbiological properties after the establishment of leguminous shrub Caragana microphylla Lam. plantation on sand dune in the Horqin Sandy Land of Northeast China. Ecol Eng. 2011; 37(10): 1467-1475.

15. Li PX, Wang N, He WM, Krüsi BO, Gao SQ, Zhang SM, et al. Fertile islands under Artemisia ordosica in inland dunes of northern China: Effects of habitats and plant developmental stages. J Arid Environ. 2008; 72: 953-963.

16. Maestre FT, Cortina J, Bautista S, Bellot J, Vallejo R. Small-scale environmental heterogeneity and spatiotemporal dynamics of seedling survival in a degraded semiarid ecosystem. Ecosystems. 2003; 6: 630-643.

17. El-Bana MI, Nijs I, Kockelbergh F. Microenvironmental and vegetational heterogeneity induced by phytogenic nebkhas in an arid coastal ecosystem. Plant Soil. 2002; 247: 283-293.

18. Anderson TM, McNaughton SJ, Ritchie ME. Scale-dependent relationships between the spatial distribution of a limiting resource and plant species diversity in an African grassland ecosystem. Oecologia. 2004; 139: 277-287. PMID: 15007724

19. Rossi RE, Mulla DJ, Journel AG, Franz EH. Geostatistical tools for modeling and interpreting ecological spatial dependence. Ecol Monogr. 1992; 62: 277-314.

20. Lu SL, Liu SW, Wu ZL, Ho TN, Pan JT. Flora Qinghaiica. Xining: Qinghai People's Publishing House; 1996. (in Chinese).

21. Institute of Soil Science, Chinese Academy of Sciences (ISSCAS). Physical and Chemical Analysis Methods of Soils. Shanghai: Shanghai Science Technology Press; 1978. (in Chinese).

22. Yang ZP, Zhang Q, Wang YL, Zhang JJ, Chen MC. Spatial and temporal variability of soil properties under Caragana microphylla shrubs in the northwestern Shanxi Loess Plateau, China. J Arid Environ. 2011; 75: 538-544.

23. Zuo XA, Zhao XY, Zhao HL, Zhang TH, Guo YR, Li YQ, et al. Spatial heterogeneity of soil properties and vegetation-soil relationships following vegetation restoration of mobile dunes in Horqin Sandy Land, Northern China. Plant Soil. 2009; 318: 153-167.

24. Doblas-Miranda E, Sánchez-Piñero F, González-Megías A. Different microhabitats affect soil macroinvertebrate assemblages in a Mediterranean arid ecosystem. Appl Soil Ecol. 2009; 41(3): 329-335.

25. Titus JH, Nowak RS, Smith SD. Soil resource heterogeneity in the Mojave Desert. J Arid Environ. 2002; 52(3): 269-292.

26. Sebasti MT. Role of topography and soils in grassland structuring at the landscape and community scales. Basic Appl Ecol. 2004; 5(4): 331-346.

27. Seibert J, Stendahl J, Sirensen R. Topographical influences on soil properties in boreal forests. Geoderma. 2007; 141(1-2): 139-148.

28. Li CJ, Li Y, Ma J, Fan LL, Wang QX. Spatial heterogeneity of soil chemical properties between HaloxyIon persicum and Haloxylon ammodendron populations. J Arid Land. 2010; 2: 257-265.

29. Cao CY, Jiang DM, Teng XH, Jiang Y, Liang WJ, Cui ZB. Soil chemical and microbiological properties along a chronosequence of Caragana microphylla Lam. plantations in the Horqin Sandy land of northeast China. Appl Soil Ecol. 2008; 40: 78-85.

30. Chen BM, Wang GX, Cheng DL, Deng JM, Peng SL, An FB. Vegetation Change and Soil Nutrient Distribution along an Oasis-Desert Transitional Zone in Northwestern China. J Integr Plant Biol. 2007; 49: 1537-1547.

31. Isselin-Nondedeu F, Bédécarrats A. Influence of alpine plants growing on steep slopes on sediment trapping and transport by runoff. Catena. 2007; 71: 330-339.

32. Gao LF, Hu ZA, Wang HX. Genetic diversity of rhizobia isolated from Caragana intermedia in Maowusu sandland, north of China. Lett Appl Microbiol. 2002; 35(4): 347-352. PMID: 12358701

33. Bhark EW, Small EE. Association between plant canopies and the spatial patterns of infiltration in shrubland and grassland of the Chihuahuan Desert, New Mexico. Ecosystems. 2003; 6(2): 0185-0196.

34. Xie GH, Steinberger $Y$. Temporal patterns of $C$ and $N$ under shrub canopy in a loessial soil desert ecosystem. Soil Biol Biochem. 2001; 33(10): 1371-1379. 
35. Martinez-Meza E, Whitford WG. Stemflow, through fall and canalization of stem flow by roots in three Chihuahuan desert shrubs. J Arid Environ. 1996; 32(3): 271-287.

36. Huang G, Zhao XY, Zhang TH, Su YG. pH and nutrition properties of rhizosphere soils of three shrub species in Horqin Sandy Land. Scientia Silvae Sinicae. 2007; 43(8): 138-142. (in Chinese with English abstract). 